\title{
Apoteker dan Konsep Kolaborasi Interprofesionalitas Tenaga Kesehatan dalam Program JKN
}

\author{
Decky Ferdiansyah \\ Badan Perencanaan Pembangunan Daerah (Bappeda) Provinsi Lampung, Indonesia \\ email: dqapt2@gmail.com
}

\section{Abstrak :}

Kesehatan merupakan hak asasi warga negara dan salah satu unsur kesejahteraan umum yang harus diwujudkan dalam kehidupan bernegara. Perwujudan tersebut dilakukan untuk mencapai derajat kesehatan individu dan masyarakat yang setinggitingginya. Pemerintah melaksanakan sistem jaminan sosial nasional di bidang kesehatan dengan nama Program Jaminan Kesehatan Nasional (Program JKN). Program JKN dirancang sebagai suatu program jaminan perlindungan kesehatan kepada peserta untuk memperoleh manfaat pemeliharaan kesehatan dan perlindungan dalam memenuhi kebutuhan dasar kesehatan. Upaya kesehatan dapat dimaknai sebagai setiap kegiatan atau serangkaian kegiatan yang bertujuan untuk memelihara dan meningkatkan derajat kesehatan individu dan masyarakat yang setinggi-tingginya. Sebagai salah satu jenis tenaga kesehatan, apoteker memiliki peran yang cukup penting dalam dimensi pelayanan kesehatan. Apoteker memiliki kompetensi berupa pengetahuan, keterampilan dan kewenangan di bidang kefarmasian, makanan dan alat kesehatan. Beberapa pihak menyebutkan tenaga kesehatan harus melakukan peran kolaborasi interprofesional. Yang dimaksud dengan kolaborasi interprofesional adalah interaksi dua atau lebih tenaga kesehatan yang berbeda untuk menghasilkan pemahaman bersama yang tidak akan mungkin tercapai jika mereka bekerja sendiri-sendiri. Menjadi tantangan yang tidak mudah bagi tenaga kesehatan di Indonesia untuk menjalankan kolaborasi interprofesional tenaga kesehatan tersebut.

Keyword : Apoteker, interprofesionalitas, tenaga kesehatan, JKN

\section{Outline}

- Pendahuluan

- Tenaga Kesehatan dalam Upaya Kesehatan

- Kesimpulan

\section{Pendahuluan}

Pemerintah melaksanakan sistem jaminan sosial nasional di bidang kesehatan dengan nama Program Jaminan Kesehatan Nasional (Program JKN). Program JKN dirancang sebagai suatu program jaminan perlindungan kesehatan kepada peserta untuk memperoleh manfaat pemeliharaan kesehatan dan perlindungan dalam memenuhi kebutuhan dasar kesehatan. Melalui program ini diharapkan agar setiap warga negara memiliki salah satu bentuk perlindungan sosial, sehingga kesejahteraan sosial dapat diwujudkan. Program JKN dilaksanakan sepenuhnya oleh BPJS Kesehatan sejak awal tahun 2014. 
Selain merupakan amanat undang-undang, Program JKN juga merupakan salah satu langkah pemerintah Indonesia untuk mewujudkan komitmen global sebagaimana amanat Resolusi World Health Assembly (WHA) ke-58 tahun 2005 di Jenewa yang menginginkan setiap negara mengembangkan dan menerapkan konsep Universal Health Coverage (UHC) bagi seluruh penduduknya.

\section{Tenaga Kesehatan dalam Upaya Kesehatan}

Upaya kesehatan dapat dimaknai sebagai setiap kegiatan atau serangkaian kegiatan yang bertujuan untuk memelihara dan meningkatkan derajat kesehatan individu dan masyarakat yang setinggi-tingginya.

Upaya kesehatan adalah salah satu dimensi dalam sistem kesehatan nasional. Sekalipun terdapat dimensi-dimensi lainnya, upaya kesehatan memegang peranan yang sangat vital dalam sistem kesehatan nasional. Inilah muara dari sistem kesehatan secara keseluruhan dan dimensi kesehatan yang sangat terlihat serta dirasakan langsung oleh masyarakat.

Penyelenggaraan upaya kesehatan harus dilakukan oleh tenaga kesehatan sesuai dengan pengetahuan, keterampilan dan kewenangannya. Ketentuan ini dapat dipahami sebagai bentuk konkrit dari upaya menghadirkan pelayanan kesehatan yang aman dan berkualitas bagi setiap individu dan masyarakat.

Pelayanan kesehatan tidak boleh dilakukan oleh pihak-pihak yang tidak memenuhi ketentuan tersebut. Pada titik inilah, pemerintah mengintegrasikan pelayanan kesehatan ke dalam Program JKN agar upaya kesehatan tidak hanya aman dan berkualitas, namun juga terjangkau oleh berbagai semua pihak yang membutuhkannya. Jika dipahami lebih lanjut, tujuan utama dari Program JKN adalah pembenahan pada dimensi pembiayaan kesehatan. Dimensi inilah yang menjadi salah satu faktor penyebab masih rendahnya derajat kesehatan masyarakat di Indonesia.

Sebelum adanya Progam JKN, kondisi sakit yang menimpa seseorang akan diikuti dengan kondisi miskin. Akibat biaya pengobatan yang mahal, maka seseorang yang sakit harus mengeluarkan uang yang banyak untuk mendapatkan kesembuhannya. Sehingga pengeluaran yang besar pada akhirnya menyebabkan orang tersebut menjadi jatuh miskin. Jadi sebelum adanya Program JKN, beban yang didapat seseorang yang sakit adalah beban penyakit dan beban ekonomi. Maka ada istilah "sakit dahulu, miskin kemudian".

Berbicara tentang tenaga kesehatan, maka berbicara tentang setiap orang yang mengabdikan diri dalam bidang kesehatan dan memiliki pengetahuan, keterampilan dan kewenangan untuk melaksanakan pengabdian tersebut. Maka peran setiap tenaga kesehatan diberikan secara tegas dalam wilayah kewenangannya masing-masing.

Tenaga medis ada pada wilayah diagnosis penyakit, perawat pada wilayah perawatan pasien, tenaga kefarmasian pada wilayah obat-obatan dan kewenangan yang melekat pada tenaga kesehatan lainnya seperti sanitarian, epidemiolog, radiografer, nutrisionis dan lain-lain. 
Praktek pembagian wilayah kewenangan ini banyak dijumpai di berbagai negara. Sehingga tidak dikenal dominasi tenaga kesehatan yang satu terhadap yang lain. Setiap profesi saling menghormati batas wilayah kewenangannya.

\section{Peran Apoteker dalam Pelayanan Kesehatan}

Sebagai salah satu jenis tenaga kesehatan, apoteker memiliki peran yang cukup penting dalam dimensi pelayanan kesehatan. Apoteker memiliki kompetensi berupa pengetahuan, keterampilan dan kewenangan di bidang kefarmasian, makanan dan alat kesehatan. Dalam ketentuan formal, pelayanan kefarmasian didefinisikan sebagai suatu pelayanan langsung dan bertanggung jawab kepada pasien yang berkaitan dengan sediaan farmasi dengan maksud mencapai hasil yang pasti untuk meningkatkan mutu kehidupan pasien.

Dari definisi tersebut dapat disimpulkan bahwa peran apoteker tidak hanya diwujudkan dalam bentuk pelayanan kepada pasien atau patient oriented, tetapi juga berkaitan dengan sediaan farmasi atau drug oriented.

Jika patient oriented terkait dengan komunikasi, informasi dan edukasi (KIE), maka drug oriented akan terkait dengan mutu obat yang diberikan kepada pasien. Pemastian mutu kedua jenis pelayanan tersebut dilakukan apoteker dari hulu ke hilir, dari proses produksi, distribusi, penyimpanan, peracikan sampai kepada pemberian obat kepada pasien.

\section{Konsep Kolaborasi Interprofesional Tenaga Kesehatan}

Beberapa pihak menyebutkan tenaga kesehatan harus melakukan peran kolaborasi interprofesional. Yang dimaksud dengan kolaborasi interprofesional adalah interaksi dua atau lebih tenaga kesehatan yang berbeda untuk menghasilkan pemahaman bersama yang tidak akan mungkin tercapai jika mereka bekerja sendiri-sendiri. Dapatkah konsep ini dijalankan di Indonesia?

Menjadi tantangan yang tidak mudah bagi tenaga kesehatan di Indonesia untuk menjalankan kolaborasi interprofesional tenaga kesehatan tersebut. Tantangan ini menjadi tidak mudah karena ada wilayah-wilayah yang telah dibatasi oleh ketentuan formal seperti peraturan perundang-undangan dan juga ketentuan nonformal seperti Standar Prosedur Operasional. Maka ketika apoteker masuk ke wilayah diagnosis, tenaga medis akan menggugat. Begitupun ketika ada seorang perawat yang melakukan pekerjaan kefarmasian, apoteker akan menggugat. Sekat keprofesian ini semakin menegaskan bahwa kolaborasi interpersonal tenaga kesehatan itu bukan hal yang mudah untuk diterapkan.

Sehingga akan muncul pertanyaan mungkinkah apoteker menjalankan peran dalam kolaborasi interprofesional tenaga kesehatan? Jawabannya bukan sesederhana mungkin atau tidak mungkin, namun ada pertanyaan yang lebih penting dan perlu menjadi bahan renungan bagi apoteker : sudah optimalkah pekerjaan kefarmasiannya dilakukan? 
Menjadi tidak relevan untuk membebankan peran kolaborasi interprofesional tenaga kesehatan kepada apoteker semata. Peran ini seharusnya menjadi beban bagi semua jenis tenaga kesehatan.

Jika semua jenis tenaga kesehatan berperan secara optimal pada wilayahnya masingmasing, maka tujuan untuk meningkatkan derajat kesehatan individu dan masyarakat akan dapat tercapai secara kolaboratif.

Kata kolaboratif haruslah ditempatkan pada pelaksanaan peran secara optimal di wilayah keprofesian masing-masing tenaga kesehatan. Pada titik ini, penggunaan kalimat kolaboratif interprofesional menjadi bias karena akan terjadi masuknya peran tenaga kesehatan pada wilayah yang bukan menjadi kewenangannya.

\section{Kesimpulan}

Jadi jika kembali kepada peran apoteker, cukuplah apoteker mengoptimalkan perannya pada drug oriented dan patient oriented sebagai sumbangsihnya pada upaya peningkatan derajat kesehatan individu dan masyarakat. Jika ini terwujud, maka apoteker akan mampu memiliki posisi yang strategis dalam setiap upaya kesehatan, terlebih dalam Program JKN.

\section{Daftar Pustaka}

UU No. 40 Th 2004 Tentang Sistem Jaminan Sosial Nasional

UU No. 24 Th 2011 Tentang Badan Penyelenggaran Jaminan Sosial

PP No. 101 Th 2012 Tentang Penerima Bantuan Iuran Jaminan Kesehatan

PERPRES No. 32 Th 2014 Tentang Pengelolaan dan Pemanfaatan dana Kapitasi Jaminan Kesehatan Nasional pada Fasilitas Kesehatan Tingkat Pertama milik Pemerintah Daerah 